ORIGINAL ARTICLE

\title{
Prolonged use of letrozole causes morphological changes on gonads in Galea spixii
}

\author{
Maria Angelica Machado Arroyo ${ }^{1}$ (D), Paulo Ramos da Silva Santos ${ }^{1}$ (D), Moacir Franco de Oliveira ${ }^{2}$ (D), \\ Antônio Chaves de Assis Neto ${ }^{1 *}$ (C) \\ ${ }^{1}$ Departamento de Cirurgia, Faculdade de Medicina Veterinária e Zootecnia, Universidade de São Paulo, São Paulo, SP, Brasil \\ 2Departamento de Ciências Animais, Universidade Federal Rural do Semi-Árido, Mossoró, RN, Brasil
}

How to cite: Arroyo MAM, Santos PRS, Oliveira MF, Assis Neto AC. Prolonged use of letrozole causes morphological changes on gonads in Galea spixii. Anim Reprod. 2021;18(2):e20200029. https://doi.org/10.1590/1984-3143-AR2020-0029

\begin{abstract}
Letrozole is used as a therapeutic agent in reproductive disorders caused by high estrogen levels. Letrozole inhibits cytochrome P450 aromatase and reduces estrogen levels. However, the effects of longterm use on reproductive traits are unknown. The aim of this study was to evaluate the prolonged use of letrozole in the gonads of rodents (Spix's yellow-toothed cavy; Galea spixii). Forty-eight rodents (24 males and 24 females) were randomly divided into the treated and control groups. Letrozole administration started at 15 days of age and continued weekly until 30,45,90, and 120 days of age. The body, testis, and ovary weights were analyzed, as well as the morphological progression of spermatogenesis and folliculogenesis. Macroscopically, body weight gain and gonads weight were increased in the letrozole group. Microscopically, the ovaries of treated females showed stratified epithelium and a cellular disorder of the tunica albuginea. In the testes of treated males, the development of seminiferous tubules was delayed and sperm was absent. The collective findings indicate that the prolonged use of letrozole alters secondary sexual characteristics, and causes weight gain, reproductive changes, and male infertility.
\end{abstract}

Keywords: aromatase, estrogens, ovary, rodents, steroidogenesis, testis.

\section{Introduction}

Letrozole is a selective P450 aromatase inhibitor that decreases the amount of estrogen produced without changes in other steroidogenic pathways (Lephart, 1996; Bhatnagar, 2007). Aromatase is responsible for the biosynthesis of estrone and estradiol from androgenic hormones, such as androstenedione and testosterone, respectively (Santos et al., 2017b) (Figure 1). Therefore, the use of letrozole allows the evaluation of aromatase activity in vivo, as well as the possible effects of the inhibition of aromatase caused by an imbalance in the ratio of androgens to estrogens (Bhatnagar, 2007).

*Corresponding author: antonioassis@usp.br

Received: October 20, 2020. Accepted: June 1, 2021.

Financial support: grant number FAPESP - 2013/22708-5; and CNPQ - 03297/2015.8.

Conflicts of interest: nothing to declare.

(c) (i) Copyright (c) The Author(s). This is an Open Access article distributed under the terms of the Creative Commons Attribution License, which permits unrestricted use, distribution, and reproduction in any medium, provided the original work is properly cited. 


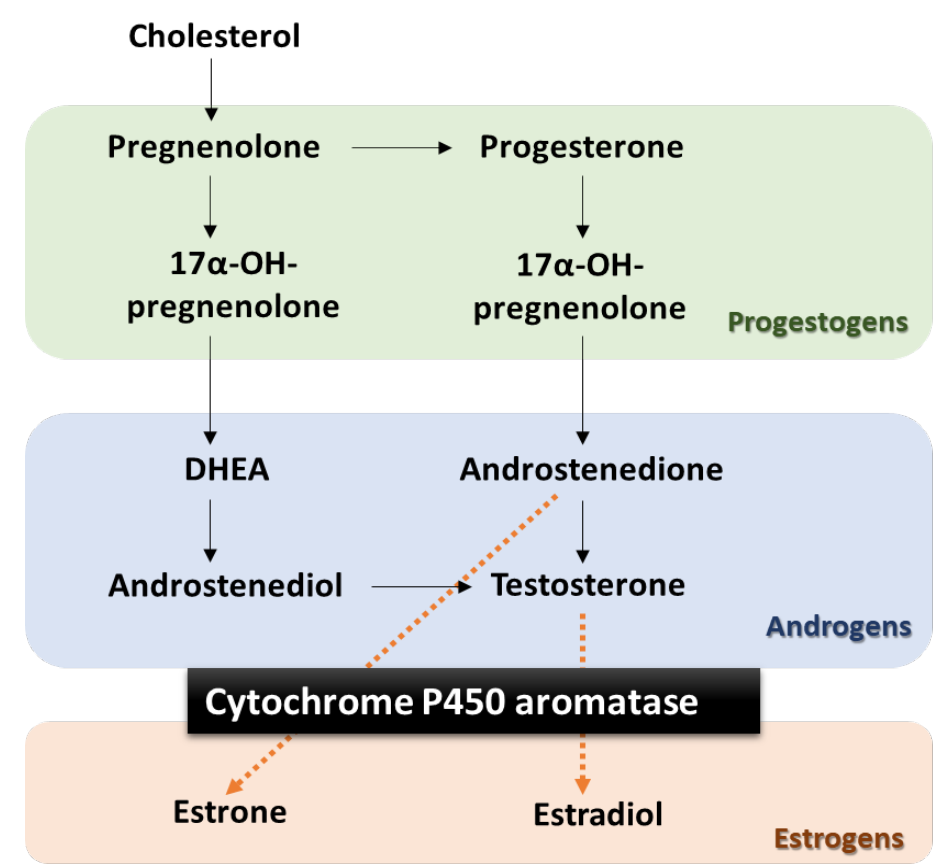

Figure 1. Simplified steroid chain diagram. The highlighted portion is cytochrome P450 aromatase, the enzyme responsible for estrogen biosynthesis from androgens.

P450 aromatase is involved in the development of nuclei of sexual dimorphisms and aromatization zones. These zones seem to be related to the control of reproduction and sexual behavior, as described in mammals, amphibians, birds, fish, and reptiles (Corbin et al., 2009; Roselli and Stormshak, 2012). Furthermore, P450 aromatase can also induce follicular and spermatogenesis development, since it exists in the gonads of several species and maintains the physiological proportion between androgens and estrogens, which are directly related to fertility (Conley and Hinshelwood, 2001).

Letrozole is widely used as a therapeutic alternative to treatments for reproductive disorders, including neoplasms (Ortega et al., 2013; Verma and Krishna, 2017). Comparative studies using several aromatase inhibitors (Lønning et al., 2003; Bhatnagar, 2007) have shown that letrozole is the most potent and selective drug that prevents intracellular estrogen synthesis and reduces hormone levels (Bhatnagar, 2007).

Letrozole is therapeutically effective in reversing reproductive illnesses related to infertility caused by hormonal imbalance, such as hypogonadism and polycystic ovary syndrome (Arroyo et al., 2019; Rambhatla et al., 2016). However, the effects of this anti-estrogen activity on gonadal activity over long periods are not clear. Reduction in estrogen levels can lead to a peripheral anabolic effect (Ortega et al., 2013), even in gonads, which causes morphological changes (Verma and Krishna, 2017; Lima et al., 2014). The effects associated with these treatments include changes in the expression of different receptors and proteins, as well as a reduction in the expression of aromatase and estradiol levels (Kondarewicz et al., 2011; Pilutin et al., 2014).

The blocking of aromatization in the prenatal androgen stage is important in establishing the pattern of sexual preference, sexual behavior, and male arousal (Olvera-Hernández et al., 2015). Even so, the effects of continued use of letrozole on the development of fertility and reproduction are not yet understood.

The aim of this study was to evaluate the effects of prolonged use of letrozole on the postnatal development of biometric reproductive parameters of rodents (Spix's yellow-toothed cavy; Galea spixii). This rodent species has been used as an experimental model for other rodents and humans to identify steroidogenic events related to reproduction and preservation (Santos et al., 2012, 2016, 2017a, 2021; Praxedes et al., 2017; Miglino et al., 2008). 


\section{Material and methods}

\section{Animals}

The animals were collected from the Centro de Multiplicação de Animais Silvestres" (IBAMA 1478912/2011) of the Universidade Federal Rural do Semiárido, located in Mossoró, Brazil. The research was authorized by the Ethics Committee of the School of Veterinary Medicine and Animal Science of the University of São Paulo, São Paulo, Brazil (protocol number: CEUA FMVZ/USP $n^{\circ} 7781180516 / 2013$ ) and by the Biodiversity Information and Authorization System (SISBIO n $41910-4)$.

G. spixii of each sex ( 24 males and 24 females) were equally divided into treated and control groups. Age was established according to the phase of sexual development previously defined in previous studies as immature (15 days-of-age), pre-pubertal (30 days), pubertal (45 days), post-pubertal (90 days), and mature sexual (120 days) (Santos et al., 2012, 2014, 2017b).

The animals were bred in enclosures measuring $5 \times 5 \mathrm{~m} 2$ and were paired in boxes according to sex. Each box $(2.5 \mathrm{~m} 2)$ had a sand floor, screen, and was covered with ceramic tiles. After delivery, the birth dates and gender identification of the puppies were recorded. The females and their puppies were separated and placed in individual enclosures $(2.5 \mathrm{~m} 2)$ to start the experiment. The diet available ad libitum included commercial rabbit feed, corn, local fruits, and water.

The experiment was conducted from June to December of 2016. According to the Laboratório de Metereologia e Climatologia at Universidade Federal Rural do Semiárido the average temperature during this time was $35.47^{\circ} \mathrm{C}$, the relative humidity was $55.61 \%$, rainfall amount was $5.70 \mathrm{~mm}$, and average wind speed was $3 \mathrm{~m} / \mathrm{s}$. The duration of the days was approximately $12 \mathrm{~h}$, with an average variation of $25 \mathrm{~min}$.

\section{Administration of drugs and euthanasia}

The first dose of letrozole (4,4'-(1H-1,2,4-triazol-1-metileno-dibenzonitrile, Femara ${ }^{\prime}$; Novartis Pharma Stein AG Stein, Switzerland) was at 15 days. Dosing continued weekly for 30, 45,90 , and 120 days. Each letrozole tablet $(2.5 \mathrm{mg}$ ) was macerated and homogenized in $0.5 \mathrm{ml}$ distilled water to produce a dose of $0.01 \mathrm{mg} / \mathrm{kg}$ body weight. The dose was delivered orally to each animal via a syringe.

All animals were anesthetized with $0.3 \mathrm{ml}$ ketamine (Cristália Prod. Quím. Farm. Ltda, Brazil) and $0.3 \mathrm{ml}$ xilasin (Syntec Ltda, Brazil). They were then euthanized with $0.4 \mathrm{ml}$ of intrathoracic potassium chloride. The animals were weighed and the right testis and right ovary were collected, weighed, fixed in 4\% paraformaldehyde (Sigma Chemical Co., USA) for $24 \mathrm{~h}$, and sectioned.

\section{Weighing}

Weight was used to indirectly assess the peripheral and/or tissue effects of letrozole's long- term action. Each rodent was weighed immediately prior to euthanasia using an WT21- LCD balance (Weightech, Davie, FL, USA). The right and right ovaries were weighed during collection using a M214A analytical balance (BEL Engineering, Monza, Italy).

\section{Morphological analysis}

Sections of the testes and ovaries were fixed in $4 \%$ paraformaldehyde (Sigma-Aldrich, St. Louis, MO, USA) for $24 \mathrm{~h}$, dehydrated in dilutions (70\%-100\%) of ethanol (Sigma-Aldrich), and embedded in paraffin. Sections of $5 \mu \mathrm{m}$ were cut and mounted. Sections were stained using hematoxylin and eosin (Sigma-Aldrich) to investigate testicular and ovarian morphology. Following deparaffinization in xylol (Sigma-Aldrich, Wicklow, Ireland) at room temperature (RT) using two solutions for 10 min each, rehydration in a descending series of ethanol 
concentrations was performed (100\%, $2 \times 5$ min; 5 min each for 90\%, 80\%, and 70\%), followed by distilled water (RT, $5 \mathrm{~min}$ ). The sections were then stained with hematoxylin for $30 \mathrm{~s}$ at RT, washed in running water for 10 min, stained with eosin at RT for $15 \mathrm{~s}$, and washed in running water for $10 \mathrm{~min}$. The slides were then dehydrated in increasing dilutions of ethanol (RT, $5 \mathrm{~min}$ 70\%, 5 min 80\%, 5 min 90\%, $2 \times 5$ min 100\%), cleaned in xylene (Sigma-Aldrich) at RT, $2 \times 10$ min, and mounted on Permount ${ }^{\circ}$ (SP15-500; Thermo Fisher Scientific, Waltham, MA, USA). The analyses were performed by light microscopy.

\section{Statistical analyses}

Body, testicular, and ovarian weights of 30-day-old animals were compared with the weight in 45, 90 and 120 day-old animals within and between the letrozole-treated and control groups using Shapiro Wilk and Bartlett test for normality and homoscedasticity (R Core Team, 2012), ANOVA followed by the Bonferroni test (IBM SPSS Statistics ${ }^{\circledR}$ Software). Statistical significance was set at $p<0.05$.

\section{Results}

\section{Body weight}

Body weight gain was greater in the group that received letrozole in both sexes and at all ages (Figure 2). Body weight in males in the control and treated groups increased up to 90 days, with a slight decrease evident at 120 days. The differences were statistically significant $(p<0.05)$. Body weights in females also increased in both groups (treated and control) and were statistically significant $(p<0.05)$.
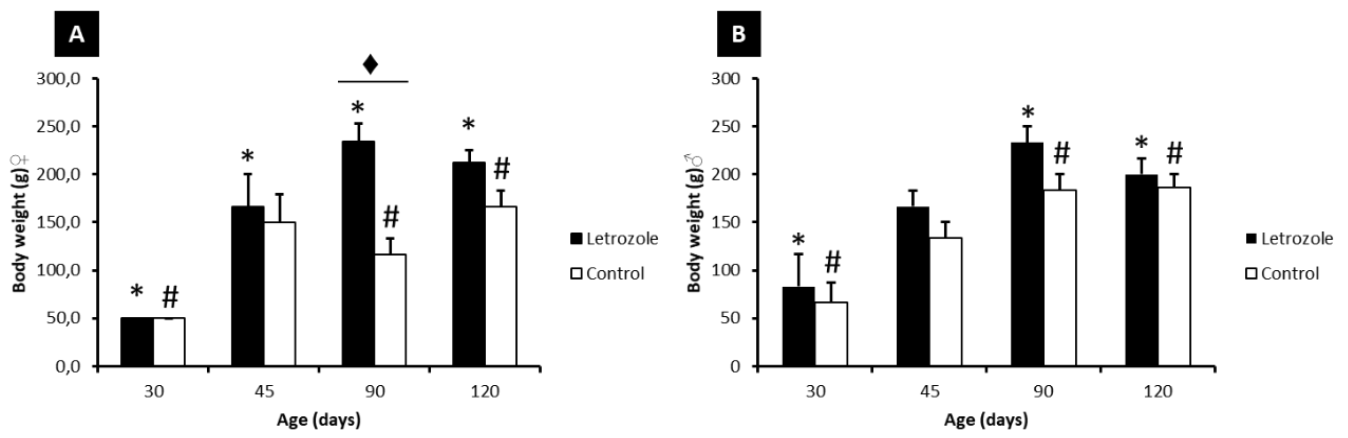

Figure 2. Letrozole effect on average body weight gain of female (A) and male (B) Spix's yellow-toothed cavy during sexual development in the letrozole and control groups. */\# $p<0.0530$ days vs. 45, 90 and 120 days; $\wedge \mathrm{p}<0.05$ letrozole vs. control.

\section{Ovarian weight}

Ovarian weight gain was greater in the group that received letrozole at 30,45, 90, and 120 days (Figure 3A). However, there was no significant difference between the age and experimental groups $(p<0.05)$. 

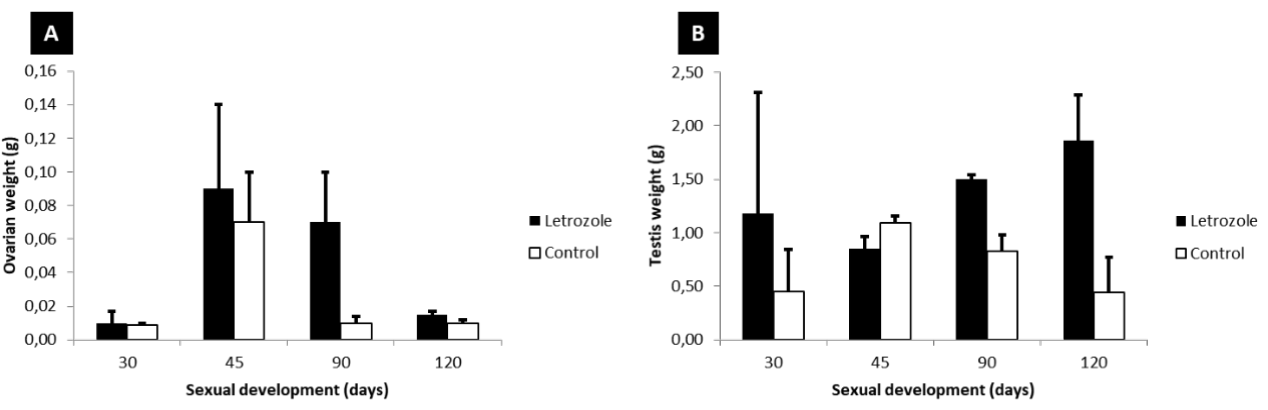

Figure 3. Effect of letrozole effect on mean testis and ovary weight gain during sexual development in the letrozole and control groups.

\section{Testes weight}

Testicular weight gain was greater in the letrozole group, except at 45 days-of-age (Figure 3B). There was no significant difference between the age and experimental groups $(p<0.05)$.

\section{Gonad histology}

In females not treated with letrozole, the surface of ovaries comprised simple cubic epithelium. The ovary was divided into two regions: a cortical zone with ovarian follicles at different stages of development, and a medullary zone with stroma and vessels. Letrozole altered the morphological development of the ovary (Figure 4). The continued use of letrozole led to stratification of the ovarian epithelium. At 120 days-of-age, micropapillary formation and cellular disorder were observed in the tunica albuginea. The treated groups did not show decreased follicular development.
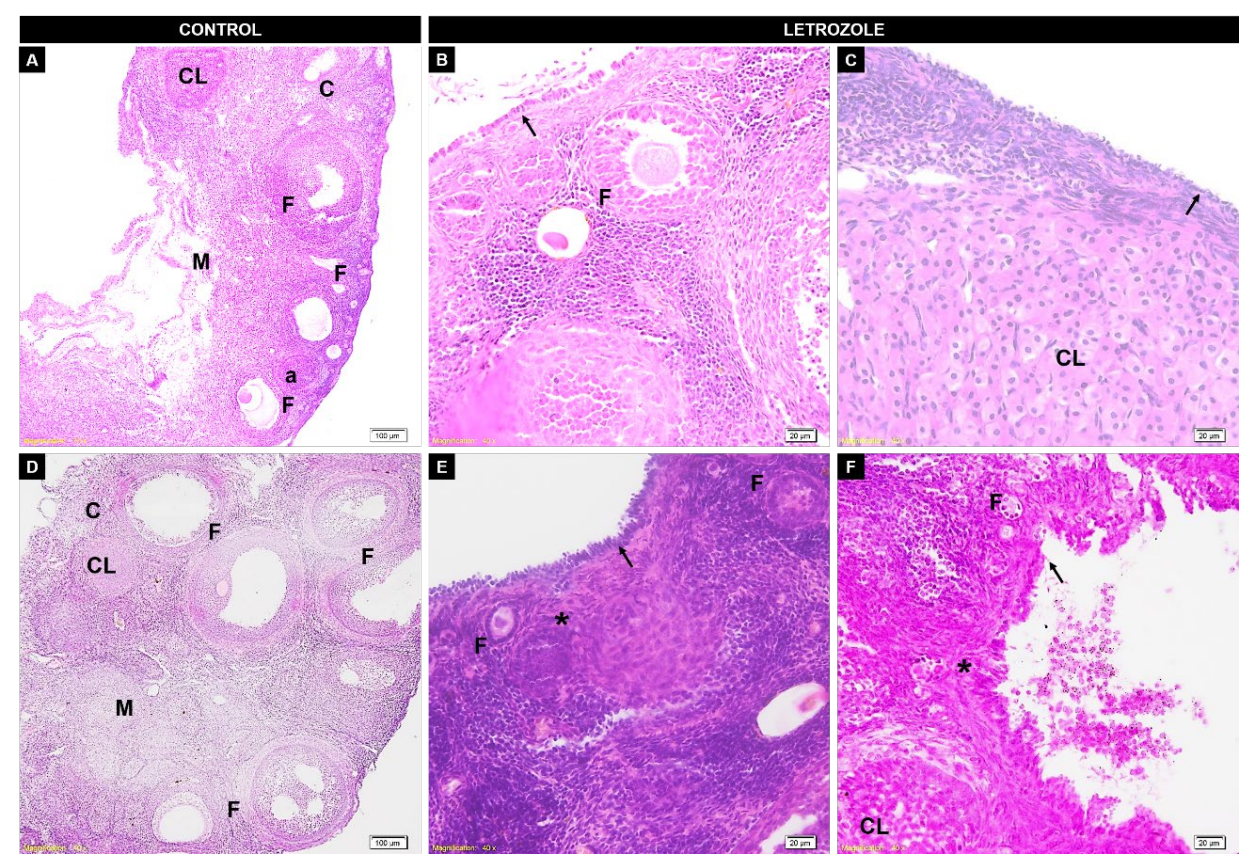

Figure 4. Effect of letrozole effect on the morphological development of the ovary of Spix's yellowtoothed cavy in the letrozole group (B-30 days, C-45 days, E-90 days, F-120 days) and the control group (A-30 days, D-90 days) groups. The arrow denotes the stratification of the epithelium. (*): Cellular disorder; (CL): corpus luteum; (C): cortical zone; (M): medullar zone; (F): follicles; (a): atresic follicle. A/C The scale bar in panels $A$ to $C$ denote $100 \mu \mathrm{m}$ (10x magnification). The scale bars in panels $B, C, E$, and $F$ denote $20 \mu \mathrm{m}$ (40x magnification). 
The testicular parenchyma of 30-day-old seminiferous tubules underwent a luminal process, with cells at different stages of the seminiferous epithelial cycle. At 45 days-of-age, the seminiferous tubules and interstitial tissue were well defined. The seminiferous tubules had a lumen, with a germinative epithelium being formed at different stages of the seminiferous epithelial cycle. In 90day-old animals, seminiferous tubules contained lumina, seminiferous epithelial cells at different stages, and spermatozoa. At 120 days-of-age, the seminiferous tubules displayed luminal areas with cells at different stages of division, allowing their classification into stages of cellular associations as described previously (Curtis and Amann, 1981). However, the animals treated with letrozole showed a different morphology after 45 days-of-age. Regression of the morphological development of seminiferous tubes was observed (Figure 5). This finding implied a reduction in spermatogenesis and the absence of spermatozoa.

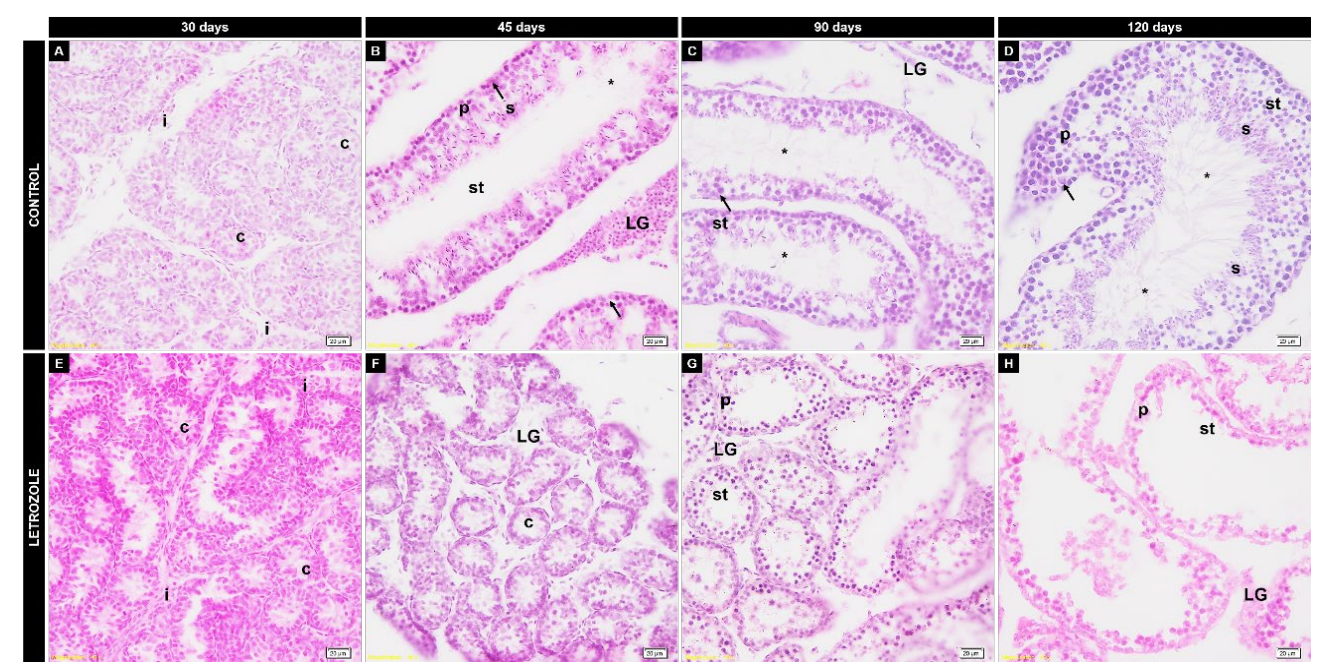

Figure 5. Effect of letrozole effect on the morphological development of the testis of Spix's yellowtoothed cavy in the control (A-D) and letrozole (E-H) groups. The findings are evidence of spermatogenic regression. (c) testicular cords, (i) internal cord with interstitial cells, (st) seminiferous tubules with spermatogonia, (sc) Sertoli cells, (p) primary spermatocytes, (s) spermatids, (*) spermatozoa, and (LG) Leydig cells. Scale bars denote $20 \mu \mathrm{m}$ (magnification 40×).

\section{Discussion}

Prolonged use of letrozole increased body weight gain and gonads, induced infertility in males, and caused dysplasia in females. Letrozole causes an imbalance in the sex hormone steroid ratio, because it induces the reduction of estrogen levels by blocking the action of cytochrome P450 aromatase (Bhatnagar, 2007). This decrease in estrogen causes alterations in secondary and reproductive characteristics in both sexes (Rambhatla et al., 2016).

Our findings suggest that the likely increase in androgen levels at both the tissue and peripheral levels may result in an anabolic effect caused by the action of letrozole (Mareck et al., 2005; Ortega et al., 2013), which promotes greater gains in body weight and gonad weight in treated animals. The findings of the present study are supported by similar results in other studies, in which increased weight gain of letrozole-treated male rats was evident (Eshet et al., 2004), as well as in females (Pouliot et al., 2013) and of ovaries (Ortega et al., 2013).

Similarly, the use of the estrogenic inhibitor fulvestrant resulted in heavier male rats, similar to the testes (Oliveira et al., 2001). In contrast, letrozole caused weight gain in male rats at doses below $0.003 \mathrm{mg} / \mathrm{kg}$ (Pouliot et al., 2013). Furthermore, we demonstrated that prolonged use of letrozole modified the development of spermatogenesis, causing azoospermia. In rats, reducing estrogen levels in spermatogenesis resulted in germ cell hanging, giant cell, and vacuum cell formation in the seminiferous epithelium, in addition to degenerating cell clusters, membrane invagination, and lipofuscin accumulation in Leydig cells (Kondarewicz et al., 2011; Pilutin et al., 2014). Nevertheless, we observed that letrozole stratified the ovary lining epithelium, but did not alter oogenesis. We believe that prolonged use of letrozole may cause 
dysplasia in women. Our aim was to support the use of letrozole (Ortega et al., 2013) and tamoxifen (Lima et al., 2014), including proliferation and formation of epithelial cell multilayers, papillomatosis, increased nucleus size, and increased epithelial invagination.

The present study is clinically important, since letrozole is widely used as an alternative therapy for hormonal decompensation in both sexes (Arroyo et al., 2019; Ortega et al., 2013; Verma and Krishna, 2017). Long-term use of letrozole in Spix's yellow-toothed cavy revealed that the inhibitor can be used for the development of secondary and reproductive traits in both males and females. This findings indicate the suitability of this rodent for studies of reproductive diseases that can affect men and women. The findings also support recommendations for further research on the steroidogenic effects of long-term use of letrozole.

\section{Conclusions}

Letrozole affects the sexual development of Spix's yellow-toothed cavy by promoting male infertility and inducing dysplasia in females upon prolonged use.

\section{Acknowledgements}

This work was supported by the São Paulo State Research Foundation (FAPESP, grant number 2013/22708-5) and Coordenação de Aperfeiçoamento de Pessoal de Nível Superior (CAPES). Prof. Assis Neto is a recipient of grants from the Conselho Nacional de Desenvolvimento Científico e Tecnológico (CNPq). We thank PhD students Felipe Vescelau Camara and Radan Elvis Matias de Oliveira for their assistance during the collection procedures.

\section{References}

Arroyo P, Ho BS, Sau L, Kelley ST, Thackray VG. Letrozole treatment of pubertal female mice results in activational effects on reproduction, metabolism and the gut microbiome. PLoS One. 2019;14(9):e0223274. http://dx.doi.org/10.1371/journal.pone.0223274. PMid:31568518.

Bhatnagar AS. The discovery and mechanism of action of letrozole. Breast Cancer Res Treat. 2007;105:717. http://dx.doi.org/10.1007/s10549-007-9696-3.

Conley A, Hinshelwood M. Mammalian aromatases. Reproduction. 2001;121(5):685-95. http://dx.doi.org/10.1530/rep.0.1210685. PMid:11427156.

Corbin CJ, Berger T, Ford JJ, Roselli CE, Sienkiewicz W, Trainor BC, Roser JF, Vidal JD, Harada N, Conley AJ Porcine hypothalamic aromatase cytochrome P450: isoform characterization, sex-dependent activity, regional expression, and regulation by enzyme inhibition in neonatal boars. Biol Reprod. 2009;81(2):388-95. http://dx.doi.org/10.1095/biolreprod.109.076331. PMid:19403926.

Curtis SK, Amann RP. Testicular development and establishment of spermatogenesis in Holstein bulls. J Anim Sci. 1981;53(6):1645-57. http://dx.doi.org/10.2527/jas1982.5361645x. PMid:7341622.

Eshet R, Maor G, Ben Ari T, Ben Eliezer M, Gat-Yablonski G, Phillip M. The aromatase inhibitor letrozole increases epiphyseal growth plate height and tibial length in peripubertal male mice. J Endocrinol. 2004;182(1):165-72. http://dx.doi.org/10.1677/joe.0.1820165. PMid:15225141.

Kondarewicz A, Kolasa A, Zawislak B, Baranowska-Bosiacka I, Marchlewicz M, Wenda-Rozewicka L, Wiszniewska B. Testis morphology in rats chronically treated with letrozole, an aromatase inhibitor. Folia Histochem Cytobiol. 2011;49(4):677-84. http://dx.doi.org/10.5603/FHC.2011.0091. PMid:22252764.

Lephart ED. A review of brain aromatase cytochrome P450. Brain Res Brain Res Rev. 1996;22(1):1-26. http://dx.doi.org/10.1016/0165-0173(96)00002-1. PMid:8871783.

Lima S, Clemenson A, Trombert B, Lecointre R, Lacoste C-R, Peoc'h M, Chene G. Morphological and immunohistochemical analysis in ovaries and fallopian tubes of tamoxifen, letrozole and clomiphene-treated rats. Arch Gynecol Obstet. 2014;290(3):553-9. http://dx.doi.org/10.1007/s00404014-3234-4. PMid:24728105. 
Lønning P, Pfister C, Martoni A, Zamagni C. Pharmacokinetics of third-generation aromatase inhibitors. Semin Oncol. 2003;30(4, Suppl 14):23-32. http://dx.doi.org/10.1016/S0093-7754(03)00305-1. PMid:14513434.

Mareck U, Sigmund G, Opfermann G, Geyer H, Thevis M, Schanzer W. Identification of the aromatase inhibitor letrozole in urine by gas chromatography/mass spectrometry. Rapid Commun Mass Spectrom. 2005;19(24):3689-93. http://dx.doi.org/10.1002/rcm.2239. PMid:16299697.

Miglino MA, Franciolli AL, de Oliveira MF, Ambrósio CE, Bonatelli M, Machado MR, Mess A. Development of the inverted visceral yolk sac in three species of Caviids (Rodentia, Caviomorpha, Caviidae). Placenta. 2008;29(8):748-52. http://dx.doi.org/10.1016/j.placenta.2008.05.007. PMid:18586321.

Oliveira CA, Carnes K, França LR, Hess RA. Infertility and Testicular Atrophy in the Antiestrogen-Treated Adult Male Rat. Biol Reprod. 2001;65(3):913-20. http://dx.doi.org/10.1095/biolreprod65.3.913. PMid:11514358.

Olvera-Hernández S, Chavira R, Fernández-Guasti A. Prenatal letrozole produces a subpopulation of male rats with same-sex preference and arousal as well as female sexual behavior. Physiol Behav. 2015;139:403-11.; http://dx.doi.org/10.1016/j.physbeh.2014.11.060. PMid:25462593.

Ortega I, Sokalska A, Villanueva JA, Cress AB, Wong DH, Stener-Victorin E, Stanley ED, Duleba AJ. Letrozole increases ovarian growth and Cyp17a1 gene expression in the rat ovary. Fertil Steril. 2013;99(3):88996. http://dx.doi.org/10.1016/j.fertnstert.2012.11.006. PMid:23200686.

Pilutin A, Misiakiewicz-Has K, Kolasa A, Baranowska-Bosiacka I, Marchlewicz M, Wiszniewska B. The immunoexpression of androgen receptor, estrogen receptors $\alpha$ and $\beta$, vanilloid type 1 receptor and cytochrome P450 aromatase in rats testis chronically treated with letrozole, an aromatase inhibitor. Folia Histochem Cytobiol. 2014;52(3):206-17. http://dx.doi.org/10.5603/FHC.2014.0024. PMid:25308736.

Pouliot L, Schneider M, DeCristofaro M, Samadfam R, Smith SY, Beckman DA. Assessment of a nonsteroidal aromatase inhibitor, letrozole, in juvenile rats. Birth Defects Res B Dev Reprod Toxicol. 2013;98(5):374-90. http://dx.doi.org/10.1002/bdrb.21080. PMid:24323897.

Praxedes ÉC, Lima GL, Silva AM, Apolinário CAC, Bezerra JAB, Souza ALP, Oliveira MF, Rodrigues APR, Silva AR. Characterisation and cryopreservation of the ovarian preantral follicle population from Spix's yellow-toothed cavies (Galea spixii Wagler, 1831). Reprod Fertil Dev. 2017;29(3):594-602. http://dx.doi.org/10.1071/RD15249. PMid:28442066.

R Core Team [database on the Internet]. R: a language and environment for statistical computing. Vienna, Austria: R Foundation for Statistical Computing; 2012 [cited 2020 Oct 20]. Available from: http://www.R-project.org/

Rambhatla A, Mills JN, Rajfer J. The role of estrogen modulators in male hypogonadism and infertility. Rev Urol. 2016;18(2):66-72. http://dx.doi.org/10.3909/riu0711. PMid:27601965.

Roselli CE, Stormshak F. Ontogeny of cytochrome p450 aromatase mRNA expression in the developing sheep brain. J Neuroendocrinol. 2012;24(3):443-52. http://dx.doi.org/10.1111/j.13652826.2011.02260.x. PMid:22128891.

Santos AC, Oliveira GB, Viana DC, Oliveira FD, Silva RS, Rici RE, de Oliveira MF, de Assis-Neto AC. Development and morphological changes in the vaginal closure membrane throughout gestation in Galea spixii (Rodentia: caviidae). Microsc Res Tech. 2016;79(5):359-64. http://dx.doi.org/10.1002/jemt.22638. PMid:26873391.

Santos AC, Viana DC, Oliveira GB, Silva RS, Oliveira MF, Assis-Neto AC Follicular development and morphological changes in the vaginal epithelium during the estrous cycle of Galea spixii. Microsc Res Tech. 2017a;80(2):167-76. http://dx.doi.org/10.1002/jemt.22784. PMid:27717109.

Santos PRS, Oliveira FD, Arroyo MAM, Oliveira MF, Castelucci P, Conley AJ, Assis AC No. Steroidogenesis during postnatal testicular development of Galea spixii. Reproduction. 2017b;154(5):645-52. http://dx.doi.org/10.1530/REP-17-0075. PMid:28982933.

Santos AC, Conley AJ, Oliveira MF, Assis AC No. Steroidogenesis during prenatal testicular development in Spix's cavy Galea spixii. Reprod Fertil Dev. 2021;33(6):392-400. http://dx.doi.org/10.1071/RD20293. PMid:33685580.

Santos PRS, Oliveira MF, Silva AR, Assis AC No. Development of spermatogenesis in captive-bred Spix's yellow-toothed cavy (Galea spixii). Reprod Fertil Dev. 2012;24(6):877-85. https://doi.org/10.1071/RD12015. 
Santos PRS, Oliveira MF, Arroyo MA, Silva AR, Rici RE, Miglino MA, Assis AC No. Ultrastructure of spermatogenesis in Spix's yellow-toothed cavy (Galea spixii). Reproduction. 2014;147(1):13-9. http://dx.doi.org/10.1530/REP-13-0452. PMid:24101585.

Verma R, Krishna A. Effect of letrozole, a selective aromatase inhibitor, on testicular activities in adult mice: both in vivo and in vitro study. Gen Comp Endocrinol. 2017;241:57-68. http://dx.doi.org/10.1016/j.ygcen.2016.02.028. PMid:26965948.

\section{Author contributions}

ACAN and MAMA: Conceptualization; writing-original draft preparation, writing--review, and editing; MFO: Methodology and Formal Analysis; PRSS: Data curation and writing, review, and editing. All the authors read and approved the manuscript. 